
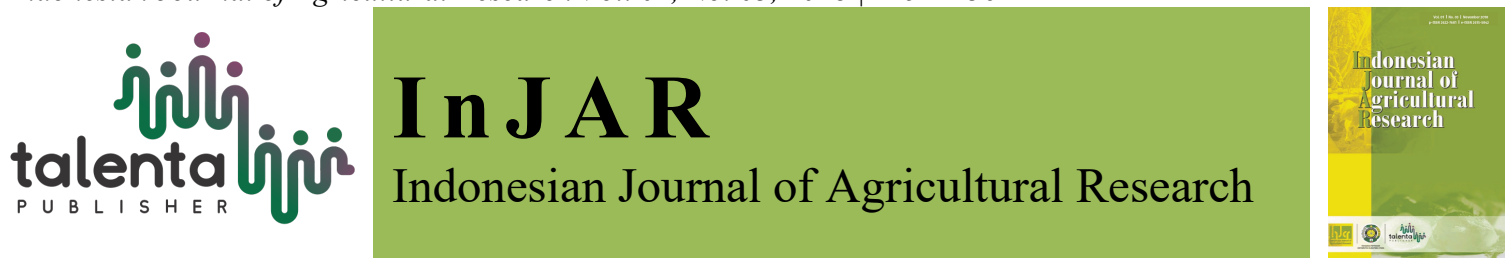

\title{
Economics of Wheat Production in Mohmand Agency, Khyber Pakhtunkhwa, Pakistan
}

\author{
Hina Gul, Sonia, Munir Khan, and Khuram Nawaz Sadozai \\ Department of Agricultural \& Applied Economics, the University of Agriculture, Peshawar, Pakistan
}

\begin{abstract}
The central theme of this research endeavour was to compute the cost and net returns of wheat crop. This study has also highlighted the significant variables contributing in wheat productivity. The study universe was two focused villages namely Malok-Korona and Peer-Qila of Ekaghund Tehsil, Mohmand Agency. The proportional allocation sampling technique was used to get the required sample size of 70 respondents. However, 26 respondents from Malok-Korona and 44 respondents from Peer-Qila were interviewed through face to face interview technique. The marked findings of this study divulge that vast majority of the farmers $(61.43 \%)$ were using certified seed and the study area was predominantly dependent upon rainfall as reported by $60 \%$ of the respondents. It is further revealed that the mean cost of production incurred by the sampled growers was estimated as Rs. 30,000 per acre. Income trend observed by 70 per cent of the respondent through wheat crop was found Rs. 40000 per acre. The average income of farmers through wheat crop was Rs.35286 per acre. The estimated results of regression analysis corroborate the expected sign of the majority of coefficient of explanatory variables. Among explanatory variables seed, irrigation and labor days were significant while urea and FYM were found insignificant for crop yield. The study recommends that attempts for awareness, supply of loans, inputs like fertilizer, pesticide, apt agriculture approaches, demonstration plots and training programs should be made available to farmers for higher wheat production in Mohmand Agency.
\end{abstract}

Keywords: cost and net return, efficiency, farm income, proportional sampling, wheat productivity

Received 08 November 2018 | Revised 13 January 2019| Accepted 14 February 2019

\section{Introduction}

Wheat (Triticum aestivum L.) is a cereal grain, originally from the Levant region of the Near East and Ethiopian Highlands, but now cultivated worldwide. The wheat production across world was observed as 699.4 million tons, making it the third most produced cereal after maize (844 million tons) in year 2011. However, the decreasing trend in the world's wheat production was recently reported by FAO which was estimated at 661.2 million tons [1]. It is evident from literature that Wheat is grown on more land area than any other commercial crop and is the most important staple food for humans. The world trade in wheat is at greater level than for all other crops combined. This is worth-mentioning that globally, wheat is the chief source of vegetable

\footnotetext{
*Corresponding author at: Department of Agricultural \& Applied Economics, Faculty of Rural Social Sciences, The University of Agriculture, Peshawar-Pakistan

E-mail address: ksaddozai@hotmail.com
} 
protein in human food, which contains high protein content than maize (corn) or rice or even the other major cereals. In terms of total production tonnages used for food, it is currently second to rice as the main human food crop and ahead of maize, after allowing for maize's more extensive use in animal feed [1].

The historic background of Wheat crop is witnessed that this crop was deemed as one of the first crops was the major food crop that could be easily cultivated on a large scale of land. Owing to its long shelf life and convenient storage techniques this cereal is preferred to be produced and utilized as a staple food. The various by and value added product includes flour for leavened, flat and steamed breads, biscuits, cookies, cakes, breakfast cereal, pasta, noodles, and couscous for fermentation to make beer, other alcoholic beverages, or befoul.

This cereal crop is commonly used as a fodder crop for livestock; further to this its straw (by product) can also be utilized as construction material. The whole grain can be milled to leave just the endosperm for white flour. The by-products of this are bran and germ. The whole grain is a concentrated source of vitamins, minerals, and protein, while the refined grain is mostly starch [1].

Many countries including Pakistan is considering Wheat as a staple food and keeping in view the importance of food security this crop is cultivated on the largest acreages in almost every part of the country. The Government of Pakistan had reported Wheat as a leading food crop which occupies the largest land area under its cultivation. The value added contribution of wheat in Pakistan is $10 \%$. While the contribution of wheat to country's GDP was 2 per cent. The latest wheat production in Pakistan was observed as 25.478 million tonnes during year 2014-15. This production was about 1.9 per cent decrease as compared the corresponding previous year whose production stood at 25.979 million tonnes. The decrease in crop production was owing to unpredicted torrential rains which resulted in great damage to wheat grain [2].

In Pakistan, wheat is grown under different cropping systems, such as; cotton - wheat, rice wheat, sugarcane - wheat, maize - wheat, fallow - wheat. Of these, Cotton-Wheat and RiceWheat systems together account about $60 \%$ of the total wheat area whereas rain-fed wheat covers more than $1.50 \mathrm{~m}$ ha area. Rotations with Maize-Sugarcane, Pulses and fallow are also important.

Wheat production in Pakistan can be divided into three distinct periods: 1947-65, prior to the release of semi-dwarf wheat's; 1966-76, the so-called "Green Revolution" period when High Yielding Varieties (HYVs) were rapidly adopted on about two thirds of total wheat area; and 1976 to date, post green revolution period when HYVs continued to spread to cover the major wheat area. A worth of Rs.220 billion wheat is produced in the country and one percent gain or loss in wheat production would be equivalent to rupees 2.20 billion. A bumper crop was 
harvested in 2006-07 because of suitable weather during the growing season, timely support price announcement, adequate supply of fertilizers [3]

Khyber Pakhtunkhwa is one of the four provinces of Pakistan and is sheltering a population of more than 20 million people .The major portion of this population i.e. about $83 \%$ is dwelling in rural areas putting a tremendous pressure on land resources. To cater for the livelihood needs of this mammoth population, the province possesses 10.17 million hectares of land. However, the cultivable area is 2.75 million hectare .Out of cultivable area only 1.8 million hectare is cultivated where as 1.08 million hectare is cultivable waste. The major chunk of cultivated land is rain fed which constitute $49 \%$ of the cultivated area. This scenario resulted in a situation where $94 \%$ farms are below the range of acres, which is a subsistence farm level Khyber Pakhtunkhwa.

Keeping in view the importance of wheat production and food security issues, the current study is designed to get detailed knowledge about the significance of input variables in wheat production and address the major issues pertinent to wheat production in Khyber Pakhtunkhwa province. The key objectives of this research endeavor is to get the estimates of cost and net return of wheat production and to determine the significance of contributing variables in the wheat yield by forwarding policy recommendation for the concerned policy makers.

\section{Materials and Methods}

\subsection{Study Universe}

This research study was carried out in Mohmand Agency Federal Administrated Tribal Area (FATA). Two villages named as Peer Qila and Malak Korona has been selected because the said villages are famous for production of wheat crop.

\subsection{Sampling Technique and Sample Size}

The information regarding farmers was gleaned from the office of local Pathwari. The testimonials provided by the said office narrates that there were 340 farmers in Village Peer Qila and 210 in Village Malok Korona.

\subsection{Sample Size Determination}

[4] introduced a simplified formula for calculating sample size. The formula is mentioned below.

$$
n=\frac{N}{1+N(e)^{2}}
$$

where: $\mathrm{N}$ is the population size and $\mathrm{e}$ is level of precision (0.1) 
Putting the values in above equation:

$$
\begin{gathered}
n=\frac{550}{1+550(0.1)^{2}} \\
\mathrm{n}=85
\end{gathered}
$$

The sample size in the research area was 85 but some respondents were not willing to take part in research study and some questionnaires were with incomplete information. That's why the sample size has been reduced to 70 .

After the selection of sampled villages, a total number of 70 respondents were interviewed by utilizing the proportional allocation sampling technique. Several authors and researchers have used proportional allocation technique for obtaining the required sample which is defined as:

$$
n_{i}=\frac{n}{N} x N_{i}
$$

where $\mathrm{ni}=$ number of sample respondents in the village; $\mathrm{i}=$ Number of villages in the study area i.e. $\mathrm{I}$ and $2 ; \mathrm{n}=$ Total sample size; $\mathrm{Ni}=$ Total number of growers in the village; $\mathrm{N}=$ Total number of growers in the research area.

By putting the values as per given data the sampled respondents are estimated as follow:

$$
\begin{gathered}
\text { Peer Qila }=340 / 550 \times 70=43.27 \\
\text { Malok koroa }=210 / 550 \times 70=26.73
\end{gathered}
$$

Table1. Number of Respondents in Selected Villages of Mohamand Agency

\begin{tabular}{lcc}
\hline \multicolumn{1}{c}{ Village } & No of farmers & Sample size \\
\hline Peer Qila & 340 & 44 \\
Malok-korona & 210 & 26 \\
Total & 550 & 70 \\
\hline
\end{tabular}

Source: Govt of Khyber Pakhtunkhwa 2016-2017

\subsection{Data Collection and Analysis}

A pretested questionnaire was designed to collect primary data from the wheat growers via face to face interview in the light of set objectives of the study. To analyse the data, a blend of SPSS and STATA has been applied to illustrate the major finding of this research endeavour.

\subsection{Costs and Net Returns of Wheat Production}

Total revenue, total cost of production and net revenue of wheat growers in the study area was calculated with the help of following equation; 


$$
\mathrm{NR}=\mathrm{TR}-\mathrm{TC}
$$

while: $\mathrm{TR}=\mathrm{PQ} * \mathrm{Q}$ and $\mathrm{TC}=\mathrm{Pxi} * \mathrm{Xi}$

where: $\mathrm{NR}=$ Net revenue; $\mathrm{TC}=$ Total cost of production; $\mathrm{TR}=$ Total revenue; $\mathrm{PQ}=$ Price of output: Q = Quantity of output; Pxi = price of input; XI = Total inputs used

\subsection{Empirical Modeling}

Linear Regression Model was used to estimate the significance of main contributing variables affecting the wheat yield. Linear regression method was used to calculate the coefficients of the model.

$$
Y=\beta 0+\beta_{1} X_{1}+\beta_{2} X_{2}+\beta_{3} X_{3}+\beta_{4} X_{4}+\beta_{5} X_{5}+\beta_{6} X_{6}+\text { ei }
$$

where: $Y=$ Total wheat yield in Mounds per acre; $\beta_{i}=$ coefficient to be estimated; $X_{1}=$ Seed quantity used in kg per acre; $X_{2}=$ Tractors hours per acre; $X_{3}=$ No. of DAP bags used per acre; $\mathrm{X}_{4}=$ No of urea bags used per acre; $\mathrm{X}_{5}=$ No. of FYM trolley per acre; $\mathrm{X}_{6}=$ No. of labor per acre; ei $=$ Error term.

\section{Results and Discussion}

\subsection{Demographic Analysis of Wheat Growers}

The wheat growers from both the villages are categorised into three age groups. Majority of the wheat growers in Malok Korona in Peer Qila were lying in the age group above 40 years. This implies that majority of wheat growers were aged and perhaps having more experience in farming profession. However very few i.e 3 wheat growers were found in the age group of below 20 years.

Table 2.Age-wise Distribution of Respondents in Selected Villages of Mohmand Agency

\begin{tabular}{lcccc}
\hline \multicolumn{1}{c}{ Village } & $\mathbf{2 0}$ years & $\mathbf{2 0 - 4 0}$ years & $\mathbf{< 4 0}$ years & Total \\
\hline Malak korona & 2 & 8 & 16 & 26 \\
Peer-Qila & 1 & 20 & 23 & 44 \\
Total & 3 & 28 & 39 & 70 \\
\hline
\end{tabular}

Source: Survey Data 2016-2017

\subsection{Educational level of Wheat Growers}

Generally, it is believed that educated are more responsive to modern technology such as certified seeds tractors, pesticides, urea ammonium nitrate, DAP, Urea etc and other improved cropping practices than the farmers which are less educated or illiterate farmers The data on educational level are given in Table 3the result indicated that $35 \%$ respondents were illiterate in the study area and the remaining 35\% were literate in the study area it indicating that 
educational level of farmers was low in the study area.

Table 3. Educational level of the Respondents

\begin{tabular}{lccccc}
\hline \multirow{2}{*}{ Village } & Illiterate & \multicolumn{4}{c}{ Literate } \\
\cline { 3 - 5 } & & > metric & Metric/intermediate & $\begin{array}{c}\text { Graduate and } \\
\text { above }\end{array}$ & Total \\
\hline Malok- & 12 & 6 & 5 & 3 & 26 \\
korona & 23 & 10 & 6 & 5 & 44 \\
Peer-Qila & 35 & 16 & 11 & 8 & 70 \\
Total & 35 & &
\end{tabular}

Source: Survey Data 2016-2017

\subsection{Tenancy Status of the Farmers}

One of farm schools thought is that, that owner of the land are good farm managers and give more efficient results in term of farm management yield and profit .Others believes that tenants are more efficient in tilling their lands and rearing their livestock's as elaborated by [5]. Therefore study of land tenure Status is important in this study to determine the tenancy status of the wheat growers and their effect on wheat yields and returns. Land tenure status gives complete picture of the farmers, ownership and the land they cultivate. The data on tenancy status are given in Table 4 , which indicated that $40 \%$ of the wheat growers were owners and $6 \%$ were tenants whereas $24 \%$ were owner-cum-tenant.

Table 4. Tenancy Status of the Farmers in Selected Villages of Mohmand Agency

\begin{tabular}{ccccc}
\hline Village & Owner & $\begin{array}{c}\text { Owner-sub } \\
\text { tenant }\end{array}$ & Tenant & Total \\
\hline Malok-korna & 13 & 10 & 3 & 26 \\
Peer-Qila & 27 & 14 & 3 & 44 \\
Total & 40 & 24 & 6 & 70 \\
\hline
\end{tabular}

Source: Survey Data 2016-2017

\subsection{Area Under Wheat by Growers}

The data on area under wheat cultivation are presented by the table below. It reveals that on average, $25 \%$ respondents were below 2 acres and 39\% respondents were 2-5 acre in the study area. The remaining $6 \%$ were above 5 acres.

Table 5. Area under Wheat by Growers in Selected Village of Mohmand Agency

\begin{tabular}{ccccc}
\hline Village & $>\mathbf{2}$ acres & $\mathbf{2 - 5}$ acres & $<\mathbf{5}$ acres & Total \\
\hline Malok-Korona & 6 & 18 & 2 & 26 \\
Peer-Qila & 19 & 21 & 4 & 44 \\
Total & 25 & 39 & 6 & 70 \\
\hline
\end{tabular}

Source: Survey Data 2016-2017

\subsection{Distribution of Farmers by Seed Used}

The results showed that the total number of farmers used certified seed were 43, in which 18 
belong to Malok-Korona and 25 belong to certified seed. The conventional seed used by the total number of farmers were 27, where 8 were from Malok-korona and 19 belong to Peer Qila. On average $61.43 \%$ and $38.57 \%$ certified and conventional seeds were utilized in the study area respectively. This implies that majority of the farmers are aware of the benefits associated with the use of certified seeds.

Table 6. Distribution of Farmers by Seed Used

\begin{tabular}{lccc}
\hline \multicolumn{1}{c}{ Village } & Certified seed & Conventional seed & Total \\
\hline Malo-korona & 18 & 8 & 26 \\
Peer-Qila & 25 & 19 & 44 \\
Total & 43 & 27 & 70 \\
\hline
\end{tabular}

Source: survey data 2016-2017

\subsection{Date of Planting}

For maximum production, wheat should be sown before 10th November because when wheat is cultivated well in time then it achieves good yield as demonstrated by Pakistan Agriculture Research Council (PARC, 2007). Table 7 shows that $45 \%$ of farmers in the study area plant wheat at optimum planting time that were before 15 th November while $25 \%$ farmers in the study area plant wheat late.

Table 7. Distribution of Farmers by Date of planting

\begin{tabular}{lccc}
\hline \multicolumn{1}{c}{ Village } & $\begin{array}{c}\text { Before 15 } \\
\text { November }\end{array}$ & $\begin{array}{c}\text { After 15 }^{\text {th }} \\
\text { November }\end{array}$ & Total \\
\hline Malok-Korona & 18 & 8 & 26 \\
Peer qila & 27 & 17 & 44 \\
Total & 45 & 25 & 70 \\
\hline
\end{tabular}

Source: survey data 2016-2017

\subsection{Cost and Net Return of Wheat Growers}

\subsubsection{Cost of wheat production}

Agricultural inputs and their cost play an important role in wheat yield. The detailed study of cost of wheat production tells us the contribution of most important inputs in wheat production and their economics significance in wheat profitability. Cost of wheat production consists of Land preparation seed sowing, labour, chemical fertilizer, farm yard manure, irrigation water pesticides, harvesting and threshing. The table 10 shows contribution of input variables towards total cost of production.

Land preparation typically involves ploughing, harrowing, and levelling the field to make it suitable for crop establishment. The respondents of the research prefer tractors for land preparation. The average land preparation cost in the study area was Rs.3000, which was $9 \%$ of total cost of wheat production. 
The quantity of seed required for one acre of land on average $50.60 \mathrm{~kg}$. The average seed and sowing cost of wheat was Rs 2024, which was $6 \%$ of the total cost of wheat production. Moreover, the cost of fertilizers i.e. Urea, DAP and FYM were Rs. 2000, Rs.4000 and Rs.1200 respectively. The transportation cost of fertilizers was calculated was Rs. 750. So, the total cost of fertilizers was Rs.10350, was 33\% of the total cost of production.

Irrigation system in the study area was Abina and cost nothing but the irrigation cost was calculated Rs. 900 , which was $2 \%$ of the cost of wheat production. Furthermore, harvesting in the study area is carried out either by family members, hired labour s or Asher. Mostly the respondents carried out harvesting by Asher. The average cost of harvesting is Rs.3000 per acre, which was $9 \%$ of the total cost of wheat production. Per acre cost of threshing was estimated Rs. 3300 that is $10 \%$ of the total cost of wheat production.

There are two kind of land rent. One kind of rent is opportunity cost and the owner of the land determines other kind rent. In study area majority of the wheat producers were owner land of their lands. Therefore, researchers took land rent as an opportunity cost. Average land rent was Rs.10 000 per acre that is $32 \%$ in the study area. Which was the second most contributor towards cost of production. In addition, the marketing cost Rs. 1000 per acre sharing 3\% to the total cost of wheat production

\subsubsection{Total cost of wheat production}

Total average total cost of wheat production includes fixed cost and variable cost. The total cost of wheat production in the study area was estimated Rs.30574 per acre, including the cost of land rent that is Rs. 10000 as shown in Table 8 .

Table.8. Cost of wheat Production per Acre in selected Villages of Mohmand Agency

\begin{tabular}{lccccc}
\hline \multicolumn{1}{c}{ Items } & Units & Quantity & Rate/unit & Total cost & $\begin{array}{c}\text { Percentage of } \\
\text { total cost }\end{array}$ \\
\hline $\begin{array}{l}\text { Tractor } \\
\text { Labour in land } \\
\text { preparation }\end{array}$ & Hrs & 3 & 700 & 2100 & \\
\hline $\begin{array}{l}\text { Total Cost on } \\
\text { Land Preparation }\end{array}$ & & 3 & 300 & 900 & \\
\hline Seed sown & $\mathrm{kg}$ & 50.60 & 40 & 20.24 & 6 \\
Urea & $\mathrm{kgs}$ & 100 & 20 & 2000 & \\
DAP & $\mathrm{Kg}$ & 100 & 40 & 4000 & \\
FYM & Trolley & 1 & 1200 & 1200 & \\
Transportation of & Rs. & & & 750 & \\
FYM & & 8 & 300 & 2400 & \\
$\begin{array}{l}\text { Application cost } \\
\text { (labour) }\end{array}$ & Days & & & $\mathbf{1 0 3 5 0}$ & $\mathbf{3 3}$ \\
\hline Total cost & & 3 & 300 & 900 & \\
\hline $\begin{array}{l}\text { irrigation cost } \\
\text { Abiana }\end{array}$ & Days & 3 & 0 & 0 & \\
\hline
\end{tabular}


Table 8. Continued

\begin{tabular}{|c|c|c|c|c|c|}
\hline Items & Units & Quantity & Rate/unit & Total cost & $\begin{array}{c}\text { Percentage of } \\
\text { total cost }\end{array}$ \\
\hline $\begin{array}{ll}\text { Total } & \text { Water } \\
\text { Charges } & \end{array}$ & & & & 900 & 2 \\
\hline Harvesting Cost & Days & 10 & 300 & 3000 & 9 \\
\hline Thresher & $\mathrm{Kg}$ & 72 & 25 & 1800 & \\
\hline $\begin{array}{l}\text { Labour } \\
\text { threshing }\end{array}$ & Days & 5 & 300 & 1500 & \\
\hline $\begin{array}{ll}\text { Total } & \text { Threshing } \\
\text { Cost } & \end{array}$ & Acre & & & 3300 & 10 \\
\hline Land Rent & Acre & & & 10000 & 32 \\
\hline Marketing Cost & & & & 1000 & 3 \\
\hline Grand Total & & & & 30574 & 100 \\
\hline
\end{tabular}

Source: Survey Data, 2016-2017

\subsubsection{Per acre gross and net revenue}

Gross return is the sum of all recipients from main product and by- product produce per acre. Thus gross return was Rs 40300 per acre in the study area (Table 8). Net Revenue can be obtained by subtracting the total cost from total revenue per acre of wheat crop [6]. Thus the net revenue was calculated as:

Net revenue $=$ Gross revenue - Total Cost

Net revenue $=$ Rs. $40300-30574$.

Net revenue $=$ Rs. 9726 per acre.

\subsubsection{Main product and by-product}

Higher wheat production depends on various factors i-e availability of improved seed, adequate supply of water (irrigation), proper ploughing, application of urea, DAP on time of sowing etc. Average wheat yield (Grain) and by-product (Bhoosa) were estimated 900 and $1990 \mathrm{~kg}$ per acre in the study area.

Table 9. Gross Net Revenue from Wheat production (Per Acre) Selected Villages of Mohmand Agency

\begin{tabular}{lccc}
\hline \multicolumn{1}{c}{ Particulars } & $\begin{array}{c}\text { Quantity } \\
\text { (Kg/acre) }\end{array}$ & Price kg (Rs) & Total value \\
\hline Main product (grains) kg & 900 & 30 & 27000 \\
By product (Bhoosa) & 1900 & 7 & 13300 \\
Gross revenue & & & 40300 \\
Total cost & & & 30574 \\
Net revenue & & & 9726 \\
\hline
\end{tabular}

Source: survey data 2016-2017 


\subsection{Regression Estimates}

This section shows the major statistical test output and regression estimated of the study area.

\subsubsection{Statistical analysis}

Detection of Heteroscedasticity: The type of data used in this study is cross sectional and mostly the cross sectional data encounters with the problem of heteroscedasticity as compare to time series data. Koenker Basset (K.B) Test was used to detect the occurrence of heteroscedasticity underlying research endeavor. $\mathrm{KB}$ test the results obtained showed that the coefficient of independent variable (PRE-2) is insignificant with P-value of 0.97 , which indicates that the data set is not confronted with the issue of heteroscedasticity. The results are given in the Table 10:

Table 10. Koenker Basset (K.B) Test Estimates for Checking Heteroscedasticity

\begin{tabular}{lcccc}
\hline $\begin{array}{c}\text { Independent } \\
\text { Variable }\end{array}$ & $\begin{array}{c}\text { Coefficient } \\
(\beta)\end{array}$ & S.E & T-ratio & $\begin{array}{c}\text { Sig } \\
\text { (P-Value) }\end{array}$ \\
\hline constant & 0.023 & 0.034 & 0.767 & 0.046 \\
PRE-2 & 0.097 & 0.021 & 4.61 & 0.943 \\
\hline
\end{tabular}

Source: Survey data, 2016-17

Detection of multicollinearity: The statistical phenomenon which has a perfect relationship between explanatory variables is called multicollinearity. In such scenario it gets difficult to find the estimates of their individual coefficient accurately. This leads towards incorrect conclusion about the dependent and explanatory variables. This problem occurs because of inappropriate data collection method, model specification, an over determined method etc.

For checking multicollinearity in the data, a test of correlation matrix was used. Only independent variables were selected for this test to check the correlation among independent variables. Table 11 shows the results of correlation matrix if the correlation between any two variables is more than 0.80 , then as a rule of thumb, we can say that the variables are correlated and there is the problem of multicollinearity. The correlation matrix shows that most of the varibales have values less than than 0.80 depicting no multicollinearity in the data. On the flip side, some variables (Qty FYM, Tractors hrs, Qty DAP) have values greater than 0.8 which means that these variables are correlated. According to [7] when the major variables of study are diagnosed with the problem of multicollinearity then do nothing so the data has been analysed further by ignoring the collinearity issue in aforementioned variables. 
Table 11. Correlation Matrix for Detecting Multicollinearity

\begin{tabular}{lccccccc}
\hline & $\begin{array}{c}\text { Qty } \\
\text { seed }\end{array}$ & $\begin{array}{c}\text { Tractor's } \\
\text { hrs }\end{array}$ & $\begin{array}{c}\text { Qty } \\
\text { DAP }\end{array}$ & $\begin{array}{c}\text { Qty } \\
\text { Urea }\end{array}$ & $\begin{array}{c}\text { Qty } \\
\text { FYM }\end{array}$ & $\begin{array}{c}\text { Labour } \\
\text { days }\end{array}$ & TItPro \\
\hline Qtyseed & 1.0000 & & & & & & \\
Tractor's hrs & 0.6411 & 1.0000 & & & & & \\
Qty DAP & 0.7604 & 0.7812 & 1.0000 & & & & \\
Qty Urea & 0.6974 & 0.5433 & 0.7436 & 1.0000 & & & \\
Qty FYM & 0.7841 & 0.8618 & 0.7988 & 0.5256 & 1.0000 & & \\
Labour days & 0.7974 & 0.7094 & 0.8291 & 0.6464 & 0.8000 & 1.0000 & \\
TltPro & 0.8443 & 0.8374 & 0.8778 & 0.7283 & 0.8829 & 0.8626 & 1.0000 \\
\hline
\end{tabular}

Source: survey data $2016-2017 *$ Oty= quantity Hrs=hours

The estimated results of regression analysis corroborate the expected sign of the majority of coefficient of explanatory variables. The estimation further illustrates that among the explanatory variables the coefficient of quantity of seed has the greatest elasticity to wheat yield. This reveals that for one percent in seed quantity there is 0.35 increases in wheat yield. The results underscores that availability of seed quantity can optimize the wheat yield. Among explanatory variables seed, irrigation and labour days are significant while urea and FYM were found insignificant. The reason for the urea's insignificant contribution towards yield can be less use by farmers due to its high price.

\begin{tabular}{llrrrrr}
\hline Model & & Unstandardized B & $\begin{array}{c}\text { Coefficients } \\
\text { Std. Error }\end{array}$ & $\begin{array}{c}\text { Standardized } \\
\text { Coefficients } \\
\text { Beta }\end{array}$ & \multicolumn{1}{l}{ t } & \multicolumn{1}{l}{ Sig } \\
\hline $1 \quad$ (Constant) & -1286.051 & 539.328 & & -2.385 & .020 \\
& Irrigation & 56.785 & 15.689 & .192 & 3.619 & .001 \\
Seed Qty & 28.825 & 13.379 & .143 & 2.155 & .035 \\
Tractors hrs & 86.923 & 21.425 & .291 & 4.057 & .000 \\
Dap & 39.906 & 19.567 & .103 & 2.039 & .046 \\
Urea & 66.606 & 38.090 & .079 & 1.749 & .085 \\
FYM & 29.754 & 32.223 & .084 & .923 & .359 \\
Labour days & 27.294 & 7.727 & .221 & 3.532 & .001 \\
\hline
\end{tabular}

a. Dependent Variable: Wheat Yield

\section{Conclusion and Recommendation}

The study was conducted in 2011 in two villages of Mohmand Agency namely Malok-Korona and Peer-Qila. The objective was to find out the cost and net return of wheat production and to determine the significance of contributing variables in the production of wheat of study area. The proportional allocation sampling technique was used to get the required sample size of 70 respondents. The study results showed that. Majority of the wheat growers were lying in the age group above 40 years. This implies that most of the farmers were illiterate. In term of land holding majority of the farmers $40 \%$ were owner of land and $24 \%$ are owner-cum tenant while only $6 \%$ were tenant. On average the area under wheat cultivation on 2-5 acres was maximum i.e. $55.71 \%$. Moreover, huge majority of the farmers $(61.43 \%)$ were using certified seed and 
moderate number of farmers were relying on the conventional seeds $(38.57 \%)$.

In term of costs incurred on average, each wheat grower spent Rs .30574 per acre on production of wheat. However, major contributor towards the total cost of production was the purchasing and transportation of fertilizers i.e. Urea, DAP and FYM. The combine cost was calculated as Rs. 103050 per acre which share $33 \%$ to the total cost of production. The second factor is land rent which shares $32 \%$ to the total cost of production. However, overall cost was Rs. 30574 per acre for production of wheat. The gross and net return to the wheat growers were Rs. 40300 and Rs. 9726 per acre.

The regression analysis revealed that explanatory variables seed, irrigation and labor days were significant while urea and FYM were found in significant for crop yield. The study recommends that attempts for awareness, supply of loans, inputs like fertilizer, pesticide, apt agriculture approaches, demonstration plots and training programs should be made available to farmers for higher wheat production in Mohmand Agency. Moreover, the average income of farmers can be increased through the use of high yielding varieties of seed, use of trained labour and timely marketing of wheat crop. Cost of production can be reduced by improved inputs and trained labour.

\section{REFERENCES}

[1] Food and Agricultural Organization (FAO). Year wise world wheat statistics. Available at: http://www.faostat.fao.org. 2012.

[2] Gop. Economics Survey of Pakistan, 2014-2015. Economics Advisory Wing. Finance Division, Islamabad, Pakistan, 2015.

[3] B. K. Marwat, Z. Hussain, and B. Gul. "Survey on weed problems in wheat crop in District Mardan," Pakistan Journal of. Weed Science, vol. 12, no. 4, pp. 353-358, 2006.

[4] T. Yamane, Statistics: An Introductory Analysis. 2nd Ed. New York: Harper and Row, 1967.

[5] M. Hossain and M. Hussain, The Bangladesh Development Studies, vol. 5, no. 3, pp. 285348, July 1977.

[6] D. L. Debertin, Agricultural Production Economics. New York: Macmillan Publishing Company, 1986.

[7] D. N. Gujarati, Basic Econometrics. International Edition. $3^{\text {rd }}$ ed., New York: McGraw Hill Book Co., 2003, pp. 905-910. 